九州大学学術情報リポジトリ

Kyushu University Institutional Repository

\title{
Genetic Variability and Characteristic Associations Analysis in Grain Sorghum
}

Duy Can, Nguyen

Laboratory of Crop Science, Faculty of Agriculture, Kyushu University

Haryanto, Totok Agung Dwi

Laboratory of Crop Science, Faculty of Agriculture, Kyushu University

Yoshida, Tomohiko

Laboratory of Crop Science, Faculty of Agriculture, Kyushu University

https://doi.org/10.5109/24245

出版情報 : 九州大学大学院農学研究院紀要. 43 (1/2)，pp. 25-30，1998-11. Kyushu University バージョン：

権利関係 : 
J. Fac. Agr., Kyushu Univ., 43 (1·2), 2530 (1998)

\title{
Genetic Variability and Characteristic Associations Analysis in Grain Sorghum
}

\section{Nguyen Duy Can, Totok Agung Dwi Haryanto and Tomohiko Yoshida}

\author{
Laboratory of Crop Science, Faculty of Agriculture, \\ Kyushu University, Fukuoka 812-8581, Japan \\ (Received May 25, 19.98 and accepted August 7, 1998)
}

\begin{abstract}
The experiment was carried out to determine the genetic variability parameters, genotypic correlations, and path-coefficients on seven traits of thirteen genotypes of Sorghum bicolor (L.) Moench. Results showed that the 13 geriotypes of sorghum exhibited a wide range of genetic variability for all seven characteristics under consideration. The phenotypic coefficient of variation $(\mathrm{PCV})$ was higher than genotypic coefficient of variation (GCV) for all traits. The highest $\mathrm{PCV}$ and GCV was obtained for dry weight of leaves. High heritability estimates coupled with high genetic advance were observed for dry weight of leaves, plant height and 100-grair weight, indicating these traits are controlled by additive gene action. Harvest index and its components had a high positive correlation with grain yield, and these traits had strongly direct or indirect effects on grain yield. From this result, it was suggested that harvest index can bc used as a selection criterion for high yield and short plart height genotypes.
\end{abstract}

\section{INTRODUCTION}

Grain sorghum (Sorghum bicolor (L.) Moench) is an important crop, which is used as food for human or feed for animals in worldwide. Current breeding efforts are concentrated on high grain yield potential, high harvest index, suitability to mechanical harvesting, insect resistance, etc. Therefore, a knowledge of the genetic attributes and the inter-relationships among characteristics such as grain yield, 100-grain weight, harvest index and its components, and the plant height is extremely necessary if the selection for the improvement of these characteristics is simultaneously occurred. Studies on genetic variability in grain sorghum have been reported by some workers. Modi and Dabholkar (1990) and Mishra et al. (1992) reported about the variation of gene action effects for days to flowering, harvest index and its components. Dabholkar et al. (1989) studied on genetics of resistance to shootfly and found that both additive and nonadditive components of genetic variability determined the inheritance of the traits. Mallick et al. (1988) reported about substantial amount of additive genes for protein and fat content in sorghum, while methionine and tryptophan content were controlled by nonadditive genes. Determinations of genotypic and phenotypic correlations among characters are useful in planning and evaluating breeding programs (Johnson et al., 1955). Genotypic correlation coefficients offer a measure of the genetic association between characteristics and may provide an important criterion of selection for grain yield. In addition, a path-coefficient analysis permits the separation of the correlation coefficient into components of direct and indirect effects, thus the relative importance or

Corresponding author: T. Yoshida (yoshidat@agr.kyıshu-u.ac.jp). 
unimportance of each component characteristic to grain yield can be evaluated (Dewey and Lu, 1959). Several studies about characteristic associations and path-coefficient analysis in a number of crop plants have been done by several breeders (Dedaniya and Pethani, 1994; Dewey and Lu, 1959; Johnson et al, 1955; Kehr and Gardner, 1960; Ramamoorthi and Jehangir, 1995; Totok and Yoshida, 1996), but such information on the nature of these associations in sorghum is scarce.

The objectives of this study are to estimate: (1) the genotypic and phenotypic variances, heritability and genetic advance, (2) the genotypic correlations among these seven characteristics, and (3) the path coefficients, in order to assess the importance of harvest index for indirect selection for high grain yield and short plant height.

\section{MATERIALS AND METHODS}

Thirteen genotypes of grain sorghum were used in the study. These comprised 2 genotypes (TX403 and Xin White) from Kansas, U.S.A; 3 genotypes (D4, D5 and D12) from ICRISAT; 3 genotypes (C8, C9 and C10) from the Chugoku Experimental Station, and $5 \mathrm{~F}_{3}$ progenies obtained from previous experiments (Can et al., 1997). The experiment was conducted during the spring season of 1997 at Kyushu University, Fukuoka, northern Kyushu. The experimental design was a randomized completed block with 3 replications. The plot size was $1.5 \times 2.0 \mathrm{~m}$ with $20 \mathrm{~cm}$ between plants and $50 \mathrm{~cm}$ between rows. Fertilizer was applied at the rate of $2 \mathrm{gm}^{-2}$ each of $\mathrm{N}, \mathrm{P}_{2} \mathrm{O}_{5}$ and $\mathrm{K}, \mathrm{O}$. The plants were watered when necessary. Hand weeding was practiced at 15 days after planting. Due to the typhoon and shootfly, some damages occurred at the flowering stage.

The observations were based on the plot and 6 average plants from each plot were recorded for eight characteristics: Days to heading were recorded as the number of days from germination to flowering. Plant height $(\mathrm{cm})$ was recorded by measuring from the ground to the base of the panicle. Dry weight of leaves $(\mathrm{g})$, dry weight of stem $(\mathrm{g})$ and harvest index (ratio of grain yield to total above-ground dry matter) were measured at maturity. Grain yield $\left(\mathrm{gm}^{-3}\right)$, panicle length $(\mathrm{cm})$ and 100-grain weight $(\mathrm{g})$ were gathered after harvesting. Analysis of variance (ANOVA) was conducted for each of characteristics. The component of variance attributable to differences among genotypes was estimated by utilizing the mean squares following Kehr and Gardner (1960) and McGill and Lonnquist (1955):

Genotypic variance $\left(\sigma_{\mathrm{g}}^{2}\right)=\left(\mathrm{M}_{2}-\mathrm{M}_{3}\right) / \mathrm{r}$, and

Phenotypic variance $\left(\sigma^{2}{ }_{\mathrm{ph}}\right)=\sigma^{2}{ }_{\mathrm{g}}+\mathrm{M}_{3}$, where $\mathrm{M}_{2}$ is the mean square for genotypes, $\mathrm{M}_{3}$ is the mean square for error and $r$ is the number of replications in ANOVA table.

Genotypic (GCV) and phenotypic (PCV) coefficient of variations were calculated by the formula as shown by Burton (after Johnson et al., 1955) as follows:

Genotypic coefficient of variation $(\mathrm{GCV})=((\sqrt{\text { genotypic variance }) /(\overline{\mathrm{x}}}) \times 100$

Phenotypic coefficient of variation $(\mathrm{PCV})=\{(\sqrt{\text { phenotypic variance }) /(\overline{\mathrm{x}}}\} \times 100$, where $(\overline{\mathrm{X}}$ is the grand mean of the population.

Heritability $(\mathrm{H})$ in broad sense and genetic advance (Gs) by the selection of a unit of standard deviation were estimated in the following manner (Borojevic, 1990; Johnson et al., 1955): 
Heritability $(\mathrm{H})=\sigma_{\mathrm{s}} / \sigma_{\mathrm{ph}}$

Genetic advance $(\mathrm{Gs})=\left(\sigma^{2}{ }_{\mathrm{g}} / \sigma^{2}{ }_{\mathrm{p} p \mathrm{~h}}\right) \times \mathrm{k} \sigma_{\mathrm{p}: \mathrm{s}}$

where $k \sigma_{j \text { i }}$ is the selection differential expressed in phenotypic standard deviations. In this study, $k$ was given the value of 2.06 .

Genotypic correlations were computed by the formula (Johnson et al., 1955) as follows:

$$
r_{g}=\frac{\operatorname{cov}_{G(A B)}}{\sqrt{\sigma_{G(A)}^{2} / \sigma^{2}{ }_{G(B)}}}
$$

where $\operatorname{cov}_{\mathrm{G}(\mathrm{AB})}, \sigma_{\mathrm{G}(\mathrm{A})}^{2}$ and $\sigma^{2}{ }_{\mathrm{G}(\mathrm{B})}$ are genotypic covariance between a given pair of characteristics (A, B) and the genotypic variance of A and B, respectively. Genotypic correlations were estimated along with path-coefficient analysis.

A path-coefficient analysis (Dewey and Li, 1959) was employed to measure the direct and indirect effects of the traits under investigation on grain yield.

\section{RESULTS AND DISCUSSION}

Estimates of mean, variance components, genotypic and phenotypic coefficients of variation, heritability and genetic advance in percent of mean are presented in Table 1. In general, phenotypic coefficients of variation (PCV) were higher than genotypic coefficients of variation (GCV) in all traits under investigation. The GCV and PCV were high for dry weight of leaves and dry weight of stem per plant $(54.4,41.1 \%$ and $57.2,26.8 \%$, respectively), which are two of the components of harvest index. High values of GCV and PCV were also observed in grain yield per plant (20.4 and $38.2 \%$ ), 100 -grain weight $(24.8,27.4 \%)$, harvest index $(19.2,25.2 \%)$ and plant height $(23.7,24.2)$. The lowest GCV and PCV was obtained for days to heading $(8.0,8.1 \%)$. Days to heading

Table 1. Estimates of mean, genotypic and phenotypic variance, genotypic and phenotypic cocfficients of variation, heritability and genetic advance in sorghum.

\begin{tabular}{lrrrrrrr}
\hline Character & Mean & \multicolumn{1}{c}{$\sigma^{2}{ }_{\mathrm{s}}$} & \multicolumn{1}{c}{$\sigma^{2}{ }_{\mathrm{ph}}$} & $\begin{array}{c}\text { GCV } \\
(\%)\end{array}$ & $\begin{array}{c}\text { PCV } \\
(\%)\end{array}$ & $\begin{array}{l}\text { Heritabi- } \\
\text { lity (\%) }\end{array}$ & $\begin{array}{l}\text { Gs (in \% } \\
\text { of mean) }\end{array}$ \\
\hline Days to heading & 69.0 & 30.6 & 31.5 & 8.0 & 8.1 & 96.9 & 7.9 \\
Plant height (cm) & 110.7 & 690.1 & 715.9 & 23.7 & 24.2 & 96.4 & 23.3 \\
Panicle length (cm) & 21.5 & 7.0 & 10.2 & 12.3 & 14.8 & 68.7 & 10.2 \\
Dry weight of & 7.6 & 17.1 & 18.9 & 54.4 & 57.2 & 90.3 & 51.7 \\
leaves per plant (g) & & & & & & & \\
Dry weight of stem & 26.8 & 51.4 & 121.2 & 26.8 & 41.1 & 42.4 & 17.4 \\
per plant (g) & & & & & & & \\
100-grain weight (g) & 1.9 & 0.2 & 0.3 & 24.8 & 27.4 & 81.9 & 22.4 \\
Harvest index (\%) & 35.3 & 46.2 & 79.4 & 19.2 & 25.2 & 58.1 & 14.6 \\
Grain yield per & 19.4 & 15.6 & 54.9 & 20.4 & 38.2 & 28.4 & 10.9 \\
plant (g) & & & & & & & \\
\hline
\end{tabular}

$\sigma{ }_{g}:$ genotypic variance; $\sigma^{\prime 2}$ : phenotypic variance, GCV: genotypic coefficient of variation; PCV: phenotypic coefficient of variation; and Gs: genetic advance in \% of mean $=\mathrm{k}\left(\left(100 \sigma{ }_{\mathrm{s}}\right) /\right.$ $\left(\mathrm{x} \sigma_{\mathrm{ph}}^{2}\right)$ ). 
and plant height exhibited the highest heritability estimlates of $96.9 \%$ and $96.4 \%$, respectively, followed by dry weight of leaves per plant $(90.3 \%)$ and 100 -grain weight $(81.9 \%)$, indicating that these characteristics are less influenced by the environment. The lowest heritability was observed in grain yield per plant (28.4\%). Genetic advance in percent of mean (Gs) was very high for dry weight of leaves $(51.7 \%)$, whereas, this parameter was the lowest for days to heading (7.9\%).

Heritability, genetic advance and genotypic coefficient of variation together could provide the best image of the amount of advance to be expected from selection (Johnson et al., 1955). In the case of dry weight of leaves per plant, high values of Gs, heritability and GCV indicated that this characteristic was controlled by additive gene action, and the selection for this trait might be effective. Similarly, high Gs coupled with high heritability and high GCV for plant height, 100-grain weight suggested that the selection might be effective for these traits. Moderate values of Gs, heritability, GCV for harvest index and dry weight of stem indicated that the improvement of these characteristics might be also possible through the selection. However, high heritability but low Gs and low GCV for days to heading and panicle length showed the involvement of nonadditive gene action, and the selection upon these characters might not be promising.

Genotypic correlation coefficients for all pairs of seven characteristics are presented in Table 2. The highest positive correlation coefficient was observed between days to heading and dry weight of leaves $(r=0.792)$. The long duration genotypes tended to produce more dry weight of leaves. Dry weight of leaves was highly associated with dry weight of stem $(r=0.630)$ and grain yield $(r=0.463)$. Plant height had a negative association with harvest index $(r=-0.547), 100$-grain weight $(r=-0.463)$, grain yield $(r=-0.382)$ and dry weight of leaves $(r=-0.322)$. In general, the tall genotypes often produce smaller seeds, higher dry weight of leaves and stem, which are components of harvest index, and lower yield as compared with the short genotypes. Dry weight of stem was negatively correlated with harvest index $(r=-0.548)$, whereas it was positively correlated with grain yield $(\mathrm{r}=0.478)$. The 100 -grain weight had a positive association with harvest index $(r=0.388)$, grain yield $(r=0.389)$ and had a negative correlation with

Table 2. Genotypic correlations between all pairs of seven characteristics in sorghum.

\begin{tabular}{|c|c|c|c|c|c|c|}
\hline Character & $\begin{array}{l}\text { Plant } \\
\text { height }\end{array}$ & $\begin{array}{l}\text { Dry weight } \\
\text { of leaves }\end{array}$ & $\begin{array}{l}\text { Dry weight } \\
\text { of stem }\end{array}$ & $\begin{array}{l}\text { 100-gram } \\
\text { wcight }\end{array}$ & $\begin{array}{l}\text { Harvest } \\
\text { index }\end{array}$ & $\begin{array}{l}\text { Grain } \\
\text { yield }\end{array}$ \\
\hline $\begin{array}{l}\text { Days to } \\
\text { hearling }\end{array}$ & $-0.397^{*}$ & $0.792 * *$ & $0.320^{*}$ & $0.300 \mathrm{~ns}$ & $0.014 \mathrm{~ns}$ & $0.357^{*}$ \\
\hline $\begin{array}{l}\text { Plant } \\
\text { height }\end{array}$ & & $-0.322 *$ & $0.201 \mathrm{~ns}$ & $-0.463^{* *}$ & $-0.547^{* *}$ & $-0.382^{*}$ \\
\hline $\begin{array}{l}\text { Dry wcight } \\
\text { of leaves }\end{array}$ & & & $0.630^{* *}$ & $0.300 \mathrm{~ns}$ & $-0.256 \mathrm{~ns}$ & $0.463^{* *}$ \\
\hline $\begin{array}{l}\text { Dry weight } \\
\text { of stem }\end{array}$ & & & & $-0.033 \mathrm{~ns}$ & $-0.548 * *$ & $0.478^{* *}$ \\
\hline $\begin{array}{l}100 \text {-grain } \\
\text { weight }\end{array}$ & & & & & $0.388^{*}$ & $0.389^{*}$ \\
\hline $\begin{array}{l}\text { Harvest } \\
\text { index }\end{array}$ & & & & & & $0.439 * *$ \\
\hline
\end{tabular}

${ }^{*},{ }^{* *}$, ns: Significant at $5 \%, 1 \%$ level, and not significant, respectively. 
Table 3. Path coefficient analysis showing dircct and indirect effects of six characters on grain yicld in sorghum.

\begin{tabular}{|c|c|c|c|c|c|c|c|}
\hline Character & $\begin{array}{l}\text { Days to } \\
\text { heading }\end{array}$ & $\begin{array}{l}\text { Plant } \\
\text { height }\end{array}$ & $\begin{array}{l}\text { Dry weight } \\
\text { of leaves }\end{array}$ & $\begin{array}{l}\text { Dry wcight } \\
\text { of stem }\end{array}$ & $\begin{array}{l}\text { lo0-grain } \\
\text { weight }\end{array}$ & $\begin{array}{l}\text { Harvest } \\
\text { index }\end{array}$ & $\begin{array}{l}\text { Grain } \\
\text { yield }\end{array}$ \\
\hline Days to heading & -0.185 & -0.013 & 0.259 & 0.285 & -0.003 & 0.014 & 0.357 \\
\hline Plant height & 0.073 & 0.033 & -0.105 & 0.179 & 0.005 & -0.567 & -0.382 \\
\hline $\begin{array}{l}\text { Dry weight of } \\
\text { leaves per plant }\end{array}$ & -0.147 & $-\overline{0.011}$ & $\underline{0.327}$ & 0.562 & -0.003 & -0.265 & 0.463 \\
\hline $\begin{array}{l}\text { Dry woight of } \\
\text { stem per plant }\end{array}$ & -0.059 & 0.007 & 0.206 & $\underline{0.891}$ & 0.0003 & -0.567 & 0.478 \\
\hline 100-grain weight & -0.055 & -0.015 & 0.098 & -0.029 & -0.010 & 0.402 & 0.389 \\
\hline Harvest index & .0 .003 & -0.018 & -0.084 & -0.488 & -0.004 & $\underline{1.035}$ & 0.439 \\
\hline Residual & 3.352 & & & & & & \\
\hline
\end{tabular}

Direct effects are in main diagonal (underlined) for each character and indircct effects via the other characters to grain yicld are in the same row.

plant height $(\mathrm{r}=-0.463)$. It was noticed that harvest index had a positive correlation with grain yicld $(\mathrm{r}=0.439)$, negatively correlated with dry weight of stem $(\mathrm{r}=-0.548)$ and plant height $(r=-0.547)$. This agreed with the findings by Borojevic (1990) that short genotypes have a higher harvest index and higher grain yield than tall genotypes. From the results we can conclude that the improvement of high yicld and short culm length is possible by increasing harvest index through the selection.

A path-coefficient analysis of the six characteristics which expressed direct or indirect effects on grain yield are presented in Table 3. Considering the direct effect of each characteristic on grain yield, the harvest index had a strong positive direct effect (1.035), followed by dry weight of stem (0.891). In the case of dry weight of leaves, which correlated with grain yield, $r=0.463$, the relative contribution of dry weight of stem as indirect effect (0.562) was more important than direct effect (0.327). Plant height had negative corrclation with grain yield $(-0.382)$ but had low positive direct effect $(0.033)$ due to high negative indirect effect via harvest index $(-0.567)$. Likewise, although 100 -grain weight had a significant association with grain yield $(\mathrm{r}=0.389)$, but it produced low negative direct effects $(-0.010)$, indicating that the reason for this correlation was due to high positive indirect effect through harvest index (0.402).

In conclusion, results from this study showed that the PCV was higher than GCV for all characteristics under investigation, indicating that these traits had interacted with the environment to some degree or the other. High GCV and PCV was obtained for dry weight of leaves, dry weight of stem, 100-grain weight, harvest index, plant height and grain yield. This indicates that the higher magnitude of variability presents in the materials and selection may be effective for the improvement of these traits. High heritability estimates coupled with high Gs were observed for dry weight of leaves, plant height and 100-grain weight, indicating these traits are controlled by additive genes action. Days to heading and dry weight of leaves had the highest positive relationship $(r=$ $0.792)$, followed by dry weight of leaves and dry weight of stem $(r=0.630)$. Harvest index and its components played an important part in contribution to grain yield. It was suggested that harvest index can be used as a selection criterion for high yield and short plant height genotypes. 


\section{REFERENCE}

Borojevic, S. 1990 Principles and methods of plant breeding. Elscvier, Amsterdam-Oxford - New York-Tokyo, PP. 1-368

Can, N. D., S. Nakamura and T. Yoshida 1997 Combining ability and genotype $\times$ environmental interaction in early maturing grair sorghum for summer seeding. :Jph. J. Crop Sci, 66: 698-705

Chaubey, I'. K. and A. K. Richharia 1993 Genetic variability, correlations and path-coefficients in Indica rices. Indian J. Genet., 53: 356-360

Dabholkar, A. R., G. S. Lal., R. C. Mishra and N. B. Barche 1989 Combining ability analysis of resistance of sorghum to shootfly. Indian J. Genet, 49:325-330

Dedaniya, A. D. and K. V. Pethani 1994 Genetic variability, correlations and path-coefficients in deshi cotton (Gossypium arboreum L.). Indian J. Genel., 54: 229-234

Dewey, D. R. and K. H. L.1 1959 A correlation and path-coefficient analysis of components of crested wheatgrass seed production. Agron. J., 51: 515-518

Johnson, H. W., H. F. Robinson and R. E. Comstox:k 1955 Estimates of genetic and envi-ronmental variability in soybeans. Agron. J., 47: 314-318

Johnson, H.W. H. F. Robinson and R. E. Comstock 1955 Genotypic and phenotypic correla-tions in soybeans and their implications in selection. Agron. J., 47: 477-482

Kehr, W. R. and C. O. Gardner 1960 Genetic variability in ranger alfalfa. Agron. J., 52: 41-44

Mallick, A. S., M. P. Gupta and A. K. Pandey 1988 Combining ability of some quality traits in grain sorghum (Sorghum bicolor (L) Moench). Indian J. Genet., 48: 6i3-68

McGill, D. P. and J. H. Lonnquist 1955 Effects of two cycles of recurrent selection for combining ability in an open-pollinated variety of corn. Agron. J., 47:319-323

Mishra, R. C., V. S. Kandalkar and G. S. Chauhan 1992 Combining ability analysis of harvest index and its components in sorghum. Indian $J$. Genet., 52: 178-182

Modi, N. and A. R. Dabholkar 1990 Combining ability analysis of harvest index and some components of harvest index in sorghuml. Indian. J Genet., 49: 281-285

Ramamoorthi, N. and K. S. Jehlangir 1995 Genetic variability in kodomillet (Paspalum scrobiculatum L.). Indian J. Genet., 55: 117-119

Totok, A. D. H. and T. Yoshida 1996 Performance and interrelationship among several characters of pearlmillet (Pennisetum typhoideum Rich.) population. J. Fac. Agr., Kyushu Unin., 41: 1-9 